\title{
Commuting, transport and urban form: Manchester and Glasgow in the mid-twentieth century
}

\author{
COLIN G. POOLEY and JEAN TURNBULL* \\ Dept of Geography, Lancaster University, Lancaster, LA1 4YB
}

\begin{abstract}
The paper explores the links between changing transport technology, individual mobility and urban form in the British cities of Manchester and Glasgow in the mid-twentieth century. The variability of individual commuting preferences is stressed, and it is argued that decisions about the provision of public transport rarely took into account the views of individual commuters. It is also suggested that factors governing modal choice have remained quite stable from the 1930s to the 1960s.
\end{abstract}

The links between transport technology, individual mobility and urban form are an important but elusive aspect of urban history. Studies of nineteenth-century cities have mainly focused on the impact of railways on urban growth, ${ }^{1}$ or on the role of omnibuses and trams in the process of suburbanization. ${ }^{2}$ Because of its size, and more fully developed public transport networks, more attention has been focused on London than on

\footnotetext{
* Research for this article was carried out during a project on the changing journey to work in Britain funded by The Leverhulme Trust. Thanks to the respondents who provided us with life histories, all those people who gave up their time to be interviewed, and to G. Brady of the Greater Glasgow Passenger Authority for access to archives on public transport in Glasgow.

1 H.J. Dyos, 'Railways and housing in Victorian London', Journal of Transport History, 2 (1955), 11-21, 90-100; idem, 'Some social costs of railway building in London', Journal of Transport History, 3 (1957), 23-30; J. Kellett, The Impact of Railways on Victorian Cities (London, 1969); J. Simmons, 'The power of the railway', in H.J. Dyos and M. Wolff (eds), The Victorian City: Images and Realities (London, 1973), 277-310; J. Hume, 'Transport and towns in Victorian Scotland', in G. Gordon and B. Dicks (eds), Scottish Urban History (Aberdeen, 1983), 197-232.

2 G. Dickinson, 'The development of suburban road passenger transport in Leeds, 1840-95', Journal of Transport History, 4 (1959-60), 214-23; S. Monroe, 'Tramway companies in Liverpool, 1859-1897', Transactions of the Historic Society of Lancashire and Cheshire, 119 (1967), 181-212; H.J. Dyos and D. Aldcroft, British Transport: An Economic Survey from the Seventeenth to the Twentieth Century (Leicester, 1969); G. Dickinson and C. Longley, 'The coming of cheap transport - a study of tramway fares on municipal systems in British provincial towns, 1900-14', Transport History, 6 (1973), 107-27; D. Aldcroft and M. Freeman (eds), Transport in the Industrial Revolution (Manchester, 1983); R. Dennis, English Industrial Cities of the Nineteenth Century (Cambridge, 1984), 110-40.
} 
provincial cities, ${ }^{3}$ and developments in the mid-twentieth century have been largely neglected by urban historians. This is surprising, as the period from the 1930s to the 1960s was an era of unprecedented change in urban transport, with the rise of the motor car, the expansion of bus, tram and trolley-bus services in some areas, the continued extensive use of walking and cycling, and the extension of intra-urban rail links. ${ }^{4}$ This paper uses a combination of archival, survey and oral evidence to examine the relationships between changes in transport provision, urban form and individual commuting behaviour in the two British industrial cities of Manchester and Glasgow.

Many factors potentially influence the relationship between commuting, transport and urban form, and the nature and direction of links between the key elements are uncertain (Figure 1). For instance, it is not clear whether changes in transport availability stimulated the decentralization of employment and housing, thus leading to new patterns of commuting; whether the suburbanization of industry and people, necessitating complex cross-city commuting flows, promoted the development of new forms of transport; or whether individual decisions about the location of home and workplace were instrumental in encouraging changes in both urban form and transport provision in cities. It is likely that all these factors operated in some places and time periods, and that cause and effect relationships will be difficult to disentangle. We can, however, identify a series of key trends that may be identified. First, new transport technologies in the twentieth century undoubtedly increased mobility for many, though they were not necessarily available to all. ${ }^{5}$ Second, changes in urban form, with the decentralization of homes and workplaces, created increasingly complex commuting patterns in the mid-twentieth century. ${ }^{6}$ Third, changes in real incomes and working arrangements, gave some (though by no means all) urban residents increased choices of where to live and work. ${ }^{7}$ Fourth, and following from these points, many people increasingly substituted longer journeys to work for migration. Whereas in the nineteenth century a change of work

3 T. Barker and M. Robbins, A History of London Transport: Passenger Travel and the Development of the Metropolis, 2 vols (London, 1963-74); A. Jackson, Semi-Detached London: Suburban Development, Life and Transport 1900-39 (London, 1973); F.M.L. Thompson (ed.), The Rise of Suburbia (Leicester, 1982); R. Haywood, 'Railways, urban form and town planning in London, 1900-1947', Planning Perspectives, 12 (1997), 57-69.

4 Dyos and Aldcroft, British Transport; Jackson, Semi-Detached London.

5 Dyos and Aldcroft, British Transport; M. Freeman, 'Transport', in J. Langton and R. Morris (eds), Atlas of Industrializing Britain (London, 1986), 80-93; N. Thrift, 'Transport and communications 1730-1914', in R. Dodgshon and R. Butlin (eds), An Historical Geography of England and Wales (London, 1990), 453-86.

6 Jackson, Semi-Detached London; J. Whitehand, 'The basis for an historic-geographical theory of urban form', Transactions of the Institute of British Geographers, 2 (1977), 400-16.

${ }^{7}$ K. Liepmann, The Journey to Work: Its Significance for Industrial and Community Life (London, 1944); R. Lawton, 'The journey to work in England and Wales: forty years of change', Tijdschrift voor Economische en Sociale Geographie, 44 (1963), 61-9; P. Daniels, 'Employment decentralization and the journey to work', Area, 1 (1970), 47-51. 


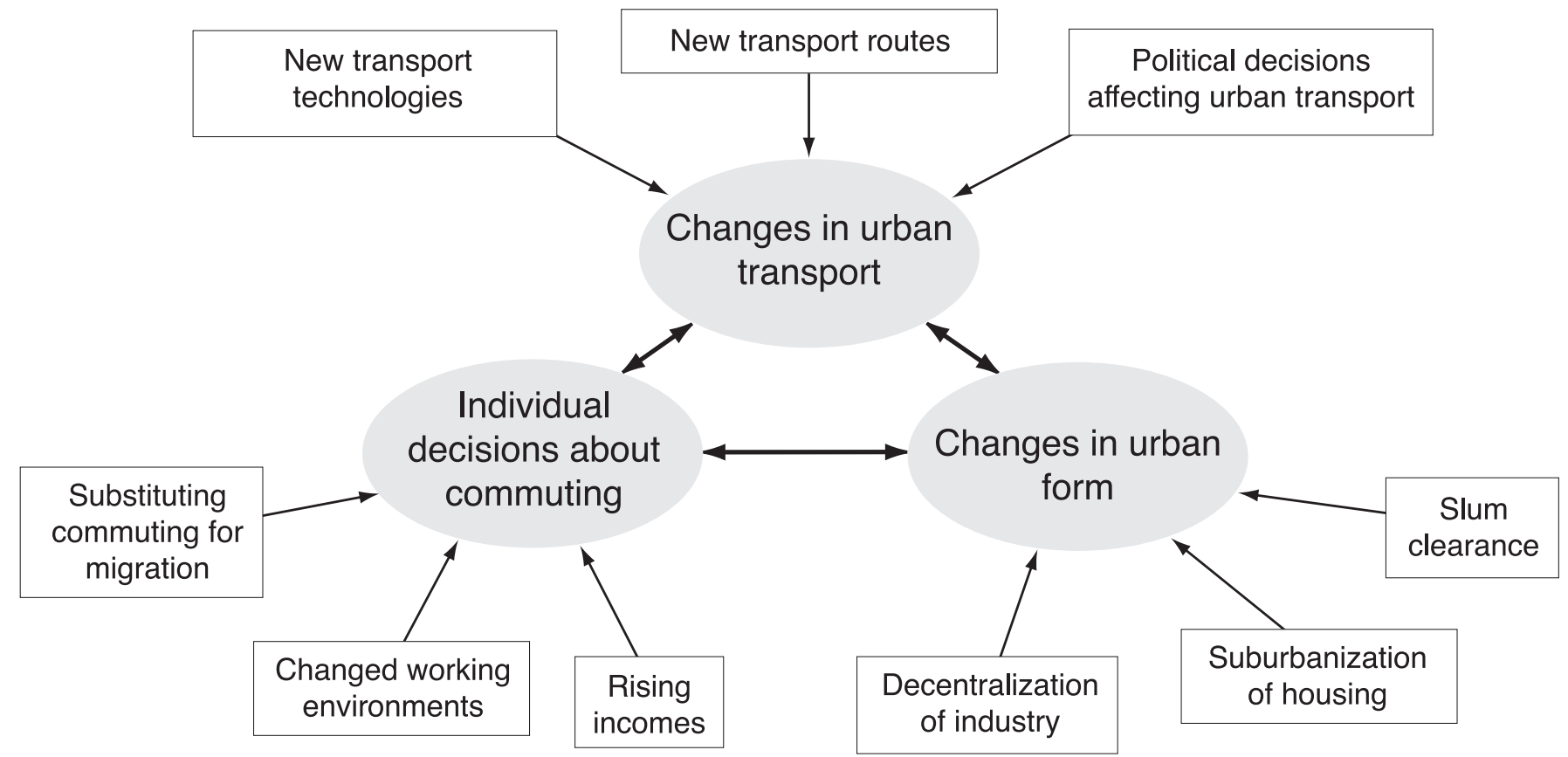

Figure 1: Factors influencing the relationship between commuting, transport and urban form 
would have necessitated a residential move, in the twentieth century it could be accommodated by a longer and more complex journey to work. $^{8}$

This paper cannot investigate all these issues in detail, but focuses on three main questions. First, what were the key changes in transport, urban form and commuting behaviour that occurred in Manchester and Glasgow from the 1930s to the 1960s? Second, what were the attitudes of individual commuters to the changes in transport and urban form that occurred in Manchester and Glasgow in the mid-twentieth century? Third, what forces drove these changes and, in particular, what was the relationship between transport provision, urban form and commuting behaviour? The paper focuses on the forty years between 1930 and 1970: this was a period of unprecedented change in urban transport and structure; for most commuters there existed a genuine choice of transport modes as public transport continued to be important and the motor car did not yet dominate urban travel; and environmental concerns about sustainable transport in cities had not gained widespread political and popular support. It is also a period that has been relatively neglected in British urban history.

\section{Data and methods}

Analysis in this paper is based on data collected from three main sources: archival material relating to transport and urban growth in Manchester and Glasgow in the twentieth century; 1,834 individual journey to work life histories collected from all parts of Britain for people who began work since the 1890s, 303 of whom worked in Glasgow or Manchester at some time during their lives; and in-depth interviews with 24 respondents who worked in Glasgow and 24 in Manchester. Data on changes in urban form and the provision of public transport in Manchester and Glasgow are drawn partly from published sources, but mainly from the reports of relevant passenger transport committees and operators in the two cities, together with other contemporary archival sources. Details of the ways in which the life history and oral history data were collected and analysed, and of the representativeness of the resulting samples, have been discussed elsewhere. ${ }^{9}$ Only a summary of the methods used is reported in this paper.

8 A. Green, T. Hogarth and R. Shackleton, 'Longer distance commuting as a substitute for migration in Britain: a review of trends, issues and implications', International Journal of Population Geography, 5 (1999), 49-67; C. Pooley and J. Turnbull, 'Moving through the city: the changing impact of the journey to work on intra-urban mobility in twentieth-century Britain', Annales de Démographie Historique, 1 (1999), 127-49.

9 C. Pooley and J. Turnbull, 'The journey to work: a century of change', Area, 31 (1999), 281-92; C. Pooley and J. Turnbull, 'Modal choice and modal change: the journey to work in Britain since 1890', Journal of Transport Geography, 8 (2000), 11-24. 


\section{$364 \quad$ Urban History}

Life history data were collected for people who began work in each decade from the 1890s to the 1980s. Information on those who began work in the late nineteenth and early twentieth centuries was collected through a network of contacts with family historians established through a previous research project on residential migration. ${ }^{10}$ Family historians were asked to provide information on their immediate ancestors (usually their parents). For those who began work from about the 1930s, respondents were identified in a number of ways. Family historians were asked to provide data for themselves, and respondents were contacted through a series of large employers, through local newspapers, other media and pensioners' clubs. All people who responded were sent a detailed data entry form requiring information on an individual's employment history, details of every new journey to work undertaken, residential history and personal characteristics. The largest number of responses related to people who began work in the mid-twentieth century (1,040 (56.7 per cent) began work in the four decades 1930-70), and the data are most reliable for the time period covered by this paper. The characteristics of respondents were compared with those recorded as in employment in the 1931, 1951 and 1971 censuses of Great Britain. Overall, the sample is quite representative of the total population with respect to gender, age and marital status (though with some under-representation of women in the 1930s, and of young and single workers in the 1970s), but does contain a substantial bias towards those in higher socio-economic groups (particularly in the 1970s). These data are used briefly in this paper to summarize commuting trends in the mid-twentieth century.

All those who provided life history data relating to themselves were asked if they would be prepared to participate in an in-depth interview, probing their experience of the journey to work in the past, and focusing especially on their reasons for making particular decisions about modes of transport and the location of home and workplace. A total of 90 respondents were selected for interview: 50 who began work in the 1920s, 1930s and 1940s were interviewed face to face (each interview lasted 1.5 - 2 hours), and a further 40 who began work later in the twentieth century were interviewed more briefly by phone. All interviews were taped, transcribed and analysed using the computer text analysis program NU.DIST. All those interviewed had begun work in one of three labour markets: London, Manchester or Glasgow, and they were selected to provide a balance of male and female respondents and to provide a broadly representative socio-economic cross-section of the population. Thus those in unskilled work were over-sampled in relation to their presence in the life history survey data. The characteristics of those interviewed are summarized in Table 1, and much of the analysis presented in this paper is drawn from the transcripts of those who

10 C. Pooley and J. Turnbull, Migration and Mobility in Britain Since the Eighteenth Century (London, 1998). 
Table 1: Profile of interview respondents

\begin{tabular}{|c|c|c|c|}
\hline & Male & Female & Total \\
\hline \multicolumn{4}{|l|}{ Decade starting work: } \\
\hline 1920s & 1 & 2 & 3 \\
\hline 1930s & 14 & 16 & 30 \\
\hline 1940s & 10 & 3 & 13 \\
\hline 1950s & 6 & 6 & 12 \\
\hline 1960s & 6 & 8 & 14 \\
\hline 1970s & 6 & 5 & 11 \\
\hline 1980s & 3 & 4 & 7 \\
\hline \multicolumn{4}{|c|}{ Labour market in which first employed: } \\
\hline London & 23 & 19 & 42 \\
\hline Manchester & 12 & 12 & 24 \\
\hline Glasgow & 11 & 13 & 24 \\
\hline \multicolumn{4}{|l|}{$\begin{array}{l}\text { Highest socio-economic group } \\
\text { achieved in working life: }\end{array}$} \\
\hline Professional & 10 & 8 & 18 \\
\hline Managerial/intermediate & 15 & 5 & 20 \\
\hline Skilled non-manual (clerical) & 6 & 22 & 28 \\
\hline Skilled manual & 13 & 2 & 15 \\
\hline Semi-skilled/unskilled manual & 2 & 7 & 9 \\
\hline Total & 46 & 44 & 90 \\
\hline
\end{tabular}

worked in Glasgow and Manchester in the period 1930-70. Data for London are not used in this paper due to the complexity and distinctiveness of metropolitan commuting patterns.

\section{The journey to work in twentieth-century Britain}

A brief summary of the main changes that have occurred in the journey to work in Britain is given to provide context for later discussion of policies and attitudes in Manchester and Glasgow. Data are drawn from the 1,834 life histories outlined above, and only the barest outlines, focusing on changes in travel time, distance and mode are presented here. More details have been published elsewhere. ${ }^{11}$ Over the century since 1890 there has been a fourfold increase in the mean one-way journey to work in Britain from $3.6 \mathrm{~km}$. (1890-99) to $14.6 \mathrm{~km}$. (1990-98). In contrast, the mean time spent travelling to work has barely doubled over the same period from 17.7 minutes to 34.5 minutes, and most of this increase occurred before the 1920s (Table 2). Changes in transport technology have allowed people to travel further, but there appears to be a threshold of acceptable travel time which has remained remarkably

11 Pooley and Turnbull, 'The journey to work'. 
Table 2: Average distance (km.) and time (min.) travelled for journeys to work in Britain since 1890 by gender

\begin{tabular}{lcccccc}
\hline \hline & \multicolumn{2}{c}{ Males } & \multicolumn{2}{c}{ Females } & \multicolumn{2}{c}{ All } \\
Decade & Distance & Time & Distance & Time & Distance & Time \\
\hline $1890-99$ & 4.0 & 17.0 & 1.8 & 21.3 & 3.6 & 17.7 \\
$1900-09$ & 3.9 & 21.5 & 3.2 & 25.4 & 3.8 & 22.4 \\
$1910-19$ & 6.2 & 27.0 & 5.1 & 26.8 & 5.9 & 13.1 \\
$1920-29$ & 6.8 & 14.5 & 6.1 & 31.3 & 6.7 & 29.0 \\
$1930-39$ & 7.0 & 30.5 & 6.8 & 31.9 & 7.0 & 13.6 \\
$1940-49$ & 8.2 & 33.8 & 7.3 & 33.1 & 7.8 & 33.5 \\
$1950-59$ & 10.1 & 33.6 & 7.4 & 34.4 & 9.0 & 33.9 \\
$1960-69$ & 12.1 & 34.6 & 7.5 & 32.1 & 10.2 & 33.5 \\
$1970-79$ & 13.1 & 34.5 & 7.6 & 28.5 & 10.3 & 31.5 \\
$1980-89$ & 15.5 & 37.3 & 8.8 & 29.4 & 12.0 & 33.1 \\
$1990-98$ & 19.4 & 39.1 & 10.5 & 30.7 & 14.6 & 34.5 \\
\hline \hline
\end{tabular}

Source: Details of 12,439 journeys to work taken from 1,834 individual life histories. Statistics relate to all modes of transport and are attributed to the decade in which a particular journey to work started.

constant since the 1930s. These trends are apparent in all areas, and for all groups of commuters, but with longer travel distances and times in London and shorter commuting distances (though not times) for women.

The significance of changing transport modes is clearly demonstrated in Table 3. From the 1890s to the 1930s walking to work was consistently the most common experience, and those who used public transport were quite evenly split between trams, trains and buses. From the 1930s to the 1950s the incidence of walking to work declined rapidly, but the use of buses and bicycles increased substantially. Train use remained stable, but the use of trams and trolley-buses declined almost to nothing. From the 1960s car use became dominant, with 40 per cent of those in employment commuting by car from the 1970s. Again the general trends are common to all areas and groups of travellers, but use of public transport has always been much higher in London than elsewhere; women have been consistently more dependent on walking and public transport; men were much more likely than women to cycle to work; and women switched to car travel some twenty years later than men. In general men have utilized faster and more independent forms of transport, whereas women have used slower and more communal means of travel. Trends in Manchester and Glasgow (Table 4) largely mirror those for the country as a whole (though small numbers in some categories mean they should be interpreted with caution), but the detailed explanation of such changes must be set within the context of changes in urban form and transport systems that were occurring in the two cities. 
Table 3: Main mode of transport for journeys to work since 1890 (\%)

\begin{tabular}{|c|c|c|c|c|c|c|c|c|}
\hline Decade & Walking & Bicycle & $\begin{array}{c}\text { Tram/ } \\
\text { trolley-bus }\end{array}$ & Bus & $\begin{array}{c}\text { Train } \\
\text { (overground) }\end{array}$ & $\begin{array}{l}\text { Under- } \\
\text { ground }\end{array}$ & $\begin{array}{l}\text { Motor } \\
\text { cycle }\end{array}$ & $\begin{array}{l}\text { Car/ } \\
\text { van }\end{array}$ \\
\hline $1900-09$ & 49.4 & 11.2 & 11.6 & 14.6 & 10.2 & 0.4 & 0.0 & 1.1 \\
\hline 1910-19 & 40.6 & 13.3 & 16.0 & 9.9 & 15.4 & 1.9 & 0.6 & 1.9 \\
\hline $1920-29$ & 28.5 & 17.5 & 10.6 & 15.3 & 17.8 & 2.3 & 3.9 & 5.2 \\
\hline $1950-59$ & 13.4 & 16.0 & 2.5 & 23.3 & 18.9 & 4.4 & 3.0 & 16.3 \\
\hline $1960-69$ & 14.0 & 5.2 & 0.2 & 18.8 & 16.2 & 5.3 & 2.6 & 35.8 \\
\hline $1970-79$ & 13.4 & 4.5 & 0.1 & 15.8 & 13.2 & 5.5 & 1.9 & 44.5 \\
\hline $1980-89$ & 10.3 & 6.1 & 0.0 & 11.7 & 15.4 & 5.4 & 1.8 & 48.5 \\
\hline 1990-98 & 7.9 & 6.1 & 0.2 & 10.1 & 17.2 & 4.5 & 0.6 & 52.8 \\
\hline Sample size & 2,083 & 1,379 & 466 & 2,073 & 2,002 & 564 & 264 & 3,108 \\
\hline
\end{tabular}

Source: As for Table 2. Statistics are calculated for the decade in which a particular journey to work started. 
Table 4: Summary of changes in the journey to work in Manchester and Glasgow since 1890

\begin{tabular}{|c|c|c|c|c|c|c|}
\hline & $\begin{array}{l}1890- \\
1919\end{array}$ & $\begin{array}{c}1920- \\
39\end{array}$ & $\begin{array}{c}1940- \\
59\end{array}$ & $\begin{array}{c}1960- \\
79\end{array}$ & $\begin{array}{c}1980- \\
98\end{array}$ & $\begin{array}{l}\text { Sample } \\
\text { size }\end{array}$ \\
\hline \multicolumn{7}{|l|}{ Manchester: } \\
\hline Mean distance (km.) & 5.5 & 6.6 & 7.6 & 7.5 & 10.4 & 792 \\
\hline Mean time (min.) & 26.4 & 31.3 & 33.2 & 29.6 & 34.7 & 619 \\
\hline$\%$ walking & 45.5 & 22.5 & 8.8 & 8.3 & 11.2 & 118 \\
\hline$\%$ car and motor bike & 2.6 & 8.2 & 19.0 & 48.7 & 42.4 & 193 \\
\hline$\%$ bicycle & 7.8 & 16.3 & 18.6 & 7.1 & 8.8 & 101 \\
\hline$\%$ train & 7.8 & 25.2 & 13.7 & 7.7 & 11.2 & 105 \\
\hline$\%$ tram and trolley bus & 27.3 & 20.4 & 1.5 & 0.0 & 0.8 & 56 \\
\hline$\%$ motor bus & 9.1 & 7.5 & 38.4 & 38.2 & 25.6 & 195 \\
\hline Sample size ${ }^{*}$ & 86 & 151 & 272 & 159 & 124 & 792 \\
\hline \multicolumn{7}{|l|}{ Glasgow: } \\
\hline Mean distance $(\mathrm{km})$. & 4.2 & 4.4 & 5.2 & 9.0 & 12.8 & 425 \\
\hline Mean time (min.) & 19.9 & 23.1 & 24.9 & 30.9 & 33.5 & 350 \\
\hline$\%$ walking & 32.1 & 27.7 & 13.9 & 15.1 & 6.3 & 62 \\
\hline$\%$ car and motor bike & 0.0 & 4.3 & 9.0 & 30.2 & 45.6 & 96 \\
\hline$\%$ bicycle & 0.0 & 4.3 & 11.5 & 2.8 & 3.6 & 23 \\
\hline$\%$ train $^{* *}$ & 10.7 & 21.3 & 13.9 & 19.8 & 24.1 & 78 \\
\hline$\%$ tram and trolley bus & 57.1 & 36.2 & 35.3 & 0.0 & 0.0 & 76 \\
\hline$\%$ motor bus & 0.0 & 6.4 & 16.4 & 32.1 & 20.5 & 80 \\
\hline Sample size ${ }^{*}$ & 28 & 49 & 123 & 111 & 114 & 425 \\
\hline
\end{tabular}

*Total number with distance given. The numbers for sub-categories may not sum to this total due to missing data.

** Includes the underground in Glasgow.

Source: As for Table 2.

\section{Manchester: public transport and urban form}

The conurbation of Manchester and Salford reached its peak population $(989,816)$ in 1931, and thereafter both cities have lost population through decentralization within north-west England, and out-migration to the Midlands and southern England. ${ }^{12}$ Although administratively separate, Manchester and Salford merge to form a single urban area and, for the most part, they are considered together in this paper. The physical extent of the built-up urban area grew rapidly in the late nineteenth century, and this was recognized by a series of boundary extensions to the City of Manchester which increased its extent from 5,935 acres in 1890 to 21,645

12 B. Rodgers, 'Manchester: metropolitan planning by collaboration and consent; or civic hope frustrated', in G. Gordon (ed.), Regional Cities in the U.K., 1890-1980 (London, 1986), 41-58; A. Kidd, Manchester (Keele, 1993). 
acres in $1913 .{ }^{13}$ By 1930 the City of Manchester had been further extended to include new corporation housing developments such as Wythenshawe (population 35,000 in 1935 and 100,000 in 1964), ${ }^{14}$ and the city stretched some $13 \mathrm{~km}$. from the city centre to the municipal boundary. The urban structure of Manchester and Salford thus reflected early decentralization, not only of housing, but also of industry, most notably through the development of the Trafford Park industrial and housing estate from $1896 .{ }^{15}$ This massive development, built on a triangle of land between the Manchester Ship Canal and other waterways, employed some 30,000 people in 1923, and 75,000 at its height in 1945. ${ }^{16}$ Thus although Manchester city centre continued to provide jobs in finance and commerce, and some manufacturing industry, by the 1930s much new employment in sectors such as oil, chemicals, electrical engineering and foodstuffs, and an increasing amount of housing, was located on the periphery of the built-up area, with consequent implications for commuting patterns. Some of these issues were recognized by contemporary plans for urban renewal and overspill developments, which moved increasing numbers of people to peripheral housing developments after 1945, although plans for one or more new towns to accommodate Manchester's overspill were repeatedly frustrated by opposition from Cheshire County Council until the 1970s. ${ }^{17}$

For the first thirty years of the twentieth century Manchester commuters depended on the municipal tram networks run by the separate corporations of Manchester and Salford. Thus by 1926 Manchester Corporation tramways operated 892 tram cars, 258 miles of track and recorded over 300 million passenger journeys in the year. ${ }^{18}$ Reciprocal agreements between Manchester, Salford and other surrounding local authorities meant that co-ordinated tram services could run throughout the whole conurbation, and tram lines extended to most of the new industrial and housing estates that were developed prior to $1930 .{ }^{19}$ At this time motor buses run by Manchester Corporation complemented, and were secondary to, the tram service; but from 1929 the Corporation pursued a deliberate policy of replacing trams with motor buses on

13 S. Simon, A Century of City Government (London, 1938).

14 E. Simon and J. Inman, The Rebuilding of Manchester (London, 1935).

15 D. Russell and G. Walker, Trafford Park, 1896-1939 (Manchester, 1979); Kidd, Manchester; D. Farnie, The Manchester Ship Canal and the Rise of the Port of Manchester, 1894-1975 (Manchester, 1980).

16 H. Clay and K. Brady (eds), Manchester at Work: A Survey (Manchester, 1929); Kidd, Manchester.

17 P. Hall et al. (eds), The Containment of Urban England (London, 1973); Rodgers, 'Manchester'; HMSO, Manchester: 50 Years of Change. Post-War Planning in Manchester (London, 1995).

18 Manchester Corporation Tramways Department (hereafter MCTramD), Annual Report, 1926.

19 Simon, A Century of City Government; E. Gray (ed.), The Tramways of Salford, 2nd edn (Salford, 1967); N. Frangopulo, Tradition in Action: The Historical Evolution of the Greater Manchester County (Wakefield, 1977). 
certain routes. Trams were increasingly blamed for causing urban traffic congestion, ${ }^{20}$ and buses were seen to be faster and more flexible, and could more cheaply provide services to new suburban developments such as Wythenshawe. ${ }^{21}$ The Corporation's decision to gradually switch from trams to buses was increasingly driven by competition from private bus companies in the city, particularly the introduction of express services, which led the Corporation to introduce its own express service from Cheadle to Heywood in $1927 . .^{22}$ In the year $1930-31$ over 39 miles of tram route were converted to motor bus operation. ${ }^{23}$ Thus whilst in 1931 84 per cent of passengers on Manchester Corporation's public transport system travelled by tram, by 1941 this had fallen to 23.9 per cent. Motor buses carried 64.6 per cent of passengers and trolley-buses, introduced to the streets of Manchester for the first time in 1938, accounted for 11.5 per cent (Table 5). ${ }^{24}$ The last tram ran in the city in January 1949 (in Salford two years earlier in 1947), and motor buses provided the main public transport system in Manchester and Salford, with a small trolley-bus network carrying 10-15 per cent of passengers until 1966 when this system also disappeared. ${ }^{25}$ By the late 1930s the Corporation had bought up all bar one of its competitor bus companies but, despite proposals in 1933, an integrated public transport system for the whole conurbation (including Salford and surrounding towns) did not emerge until the formation of the South East Lancashire and North East Cheshire Passenger Transport Authority in 1969. ${ }^{26}$

The Manchester conurbation was also relatively well served by suburban rail routes, with electrified lines to Bury (1916), Altrincham (1931) and Glossop (1954) amongst other destinations. ${ }^{27}$ These, too, competed with the municipal tramway system, and following electrification of the Altrincham line the tram route to this destination was closed. ${ }^{28}$ There were also early plans for an underground link between Manchester's main line stations but, despite serious consideration in the 1920s, 1930s, 1940s and 1970s, they were never developed. From the 1950s the use of private cars for commuting (and other journeys) reduced the number of people travelling by public transport, and passengers carried on

${ }^{20}$ Clay and Brady, Manchester at Work; Manchester Evening News, 1937-38 (Manchester Central Library, transport press cuttings, F388.4M1).

${ }^{21}$ F. Bruton, A Short History of Manchester and Salford, 2nd edn (Manchester, 1927); Manchester Corporation Transport Department (hereafter MCTranspD), A Hundred Years of Road Passenger Transport in Manchester, 1835-1935 (Manchester, 1935); Simon and Inman, The Rebuilding; Frangopulo, Tradition in Action.

22 MCTranspD, A Hundred Years; D. Eyre, Manchester's Buses 1906-1945 (Manchester, 1971).

23 MCTranspD, Annual Report, 1931.

24 MCTramD, Annual Reports; MCTranspD, Annual Reports.

25 MCTranspD, Annual Reports; Simon, A Century of City Government; Frangopulo, Tradition in Action.

26 J. Joyce, Roads and Rails of Manchester, 1900-1950 (Manchester, 1982).

27 R. Knowles, C. Law and M. Senior, 'Recent transport developments in Greater Manchester', Manchester Geographer, n.s. 12 (1991), 2-24.

28 Clay and Brady, Manchester at Work; Hall, The Containment. 
Table 5: Utilization of Corporation public transport in Manchester, 1902-65

\begin{tabular}{cccccccc}
\hline \hline Year & \multicolumn{3}{c}{ Tram } & \multicolumn{3}{c}{ Trolley-bus } & \multicolumn{2}{c}{ Motor bus } & \multicolumn{2}{l}{ Total } \\
& $\%$ & $(\mathrm{~N})^{*}$ & $\%$ & $(\mathrm{~N})^{*}$ & $\%$ & $(\mathrm{~N})^{*}$ & $(\mathrm{~N})^{*}$ \\
\hline 1902 & 100.0 & $(24)$ & - & - & - & - & $(24)$ \\
1906 & 100.0 & $(134)$ & - & - & - & - & $(134)$ \\
1911 & 100.0 & $(166)$ & - & - & - & - & $(166)$ \\
1916 & 100.0 & $(210)$ & - & - & - & - & $(210)$ \\
1921 & 100.0 & $(278)$ & - & - & - & - & $(278)$ \\
1926 & 97.0 & $(318)$ & - & - & 3.0 & $(10)$ & $(328)$ \\
1931 & 84.0 & $(293)$ & - & - & 16.0 & $(56)$ & $(349)$ \\
1936 & 59.1 & $(201)$ & - & - & 40.9 & $(139)$ & $(340)$ \\
1941 & 23.9 & $(83)$ & 11.5 & $(40)$ & 64.6 & $(224)$ & $(347)$ \\
1946 & 21.1 & $(89)$ & 15.4 & $(65)$ & 63.5 & $(267)$ & $(421)$ \\
1950 & - & - & 14.5 & $(71)$ & 85.5 & $(417)$ & $(488)$ \\
1955 & - & - & 16.2 & $(73)$ & 83.8 & $(378)$ & $(451)$ \\
1960 & - & - & 10.4 & $(42)$ & 89.6 & $(360)$ & $(402)$ \\
1965 & - & - & 4.3 & $(14)$ & 95.7 & $(313)$ & $(327)$ \\
\hline \hline
\end{tabular}

*Millions of passenger journeys

NB: Data only refer to Manchester Corporation transport and include journeys for all purposes.

Sources: MCTramD, Annual Reports, 1902-28; MCTranspD, Annual Reports, 1929-65.

Manchester Corporation's transport system fell from a peak of 488 million passenger journeys per year in 1950 to 327 million 15 years later. ${ }^{29}$ Increased car use also placed new strains on the city's urban structure from the 1950s. ${ }^{30}$ Thus, for much of the period 1930-70, commuters in the Manchester conurbation had access to a reasonably flexible and integrated public transport system, though policy decisions taken by Manchester and Salford Corporations (for instance to switch from trams to motor buses) considerably reduced choice in some areas. The impact of such decisions on commuting behaviour, and attitudes towards different forms of transport, are examined below.

\section{Glasgow: public transport and urban form}

A brief history of the development of transport and urban form in Glasgow embraces many of the same themes as that for Manchester, but with varied chronology and emphasis. Like Manchester, Glasgow grew rapidly in the late nineteenth and early twentieth century: the city's population peaked at 1,128,473 in the 1939 mid-year estimate, and Glasgow was reputed to have one of the most densely populated central

${ }^{29}$ MCTramD, Annual Reports; MCTranspD, Annual Reports.

30 Kidd, Manchester; HMSO, Manchester: 50 Years of Change. 
areas of any city in Europe in $1914 .{ }^{31}$ Repeated boundary extensions virtually doubled the city's administrative area between 1912 and the 1930s but, despite this, Glasgow retained a relatively compact urban form in the early twentieth century giving many Glaswegians the opportunity to walk to work. ${ }^{32}$ By the 1930 s all Glasgow's traditional industries (iron and steel, shipbuilding, engineering) were in decline, and the city was much less successful than Manchester at attracting new investment. ${ }^{33}$ The main centres of industrial employment were distributed along Clydeside, creating complex commuting patterns as many workers who continued to live in the city centre travelled towards peripheral dockland industrial areas, whilst others travelled in to commercial and related employment in the city centre. ${ }^{34}$ Although employment remained in largely traditional locations, and only the affluent suburbanized early, ${ }^{35}$ from the 1920s Glasgow Corporation developed substantial peripheral housing estates. Although some were relatively low density others, such as Blackhill, were of high-rise construction and proved unpopular with tenants. ${ }^{36}$ The theme of suburbanization and inner-city reconstruction continued after the Second World War, stimulated by the 1946 Clyde Valley Plan. From the late 1940s Glasgow's urban population was increasingly rehoused on both green field housing estates and the three new towns of Cumbernauld, East Kilbride and Irvine, the adoption of both strategies being a compromise between the different aspirations of the Scottish Development Office (which favoured new towns) and Glasgow Corporation which preferred overspill estates. ${ }^{37}$ By 1970 some 200,000 people had moved to peripheral estates around Glasgow, fundamentally changing patterns of daily commuting in the city. ${ }^{38}$

In 1871 Glasgow Corporation promoted one of the first tramways in the country (it built lines but leased operation to a private company until 1894 when the corporation took full control), and the tramway dominated Glasgow's urban transport system from the 1910s, when lines were extended into commuter suburbs, until the 1960s. ${ }^{39}$ Although from the 1920s trams faced competition from private bus companies, and the corporation introduced motor buses on some routes from 1924,

31 S. Checkland, The Upas Tree: Glasgow 1875-1975, and After 1975-1980 (Glasgow, 1981); M. Pacione, Glasgow: The Socio-Spatial Development of the City (London, 1995); Glasgow City Council, Glasgow Fact Sheets, 1995-96 (Glasgow, 1996).

32 Checkland, The Upas Tree; Pacione, Glasgow.

33 Checkland, The Upas Tree; Pacione, Glasgow; Glasgow City Council, Glasgow Fact Sheets.

34 Ministry of Transport, Committee of Enquiry into London Transport (London, 1955).

35 A. Gibb, Glasgow: The Making of a City (London, 1983).

36 Checkland, The Upas Tree; Pacione, Glasgow.

37 A. Slaven, The Development of the West of Scotland, 1750-1960 (London, 1975); Checkland, The Upas Tree; U. Wannup, 'Glasgow/Clydeside: a century of metropolitan evolution', in Gordon, Regional Cities in the U.K., 83-98.

38 Checkland, The Upas Tree; Gibb, Glasgow; Pacione, Glasgow.

39 M. Simpson, 'Urban transport and the development of Glasgow's West End, 1830-1914', Journal of Transport History, n.s. 1 (1971-72), 146-60. 
these did not have the same impact as in Manchester. First, the corporation reacted to private bus competition by reducing tram fares and investing in new tram cars, regarded as the best in Europe in the 1930s; second, they only introduced their own motor buses on routes not served by trams; and, third, in 1930 they introduced the Glasgow Corporation (Monopoly) Act which severely restricted private bus operation in the city. ${ }^{40}$ Although by 1938 the corporation operated some 600 motor buses, these complemented the tram service, largely linking the city centre to new peripheral housing and industrial estates not served by the tramway system. ${ }^{41}$ Thus in 1947 the trams were still carrying four times the number of passengers carried by motor buses and in 1948 (the time that trams disappeared from the streets of Manchester) the corporation took delivery of 100 new tram cars. ${ }^{42}$ However, from the mid-1940s there was increasing debate about the role of trams in the urban transport system, and the corporation embarked on a programme of gradually replacing its tram services with motor buses and trolley-buses. ${ }^{43}$ The first trolley-buses were introduced in 1949 and, with some 195 vehicles, Glasgow had the largest fleet of trolley-buses outside London. ${ }^{44}$ However, trams continued to be widely available and popular with the travelling public despite the removal of some routes. In 1953 the corporation supplemented the tram fleet with the purchase of second-hand tram cars from Liverpool, and in 1957 there were still 1,027 trams in Glasgow, carrying over 300 million passengers a year over 256 route miles (Table 6). ${ }^{45}$ However, despite their popularity the trams were the only section of the City Transport department to make a loss from the mid-1950s. As in Manchester trams were also blamed for causing congestion, ${ }^{46}$ and the motor bus came to dominate public transport. The last trams ran in Glasgow in 1962 (despite continuing to carry more passengers than any other form of public transport), and trolley-buses were withdrawn in 1967. ${ }^{47}$ The number of passengers travelling by bus peaked in the early 1960s (following the closure of the tram network), but thereafter passenger numbers dropped dramatically (from 419 million trips per annum

40 Corporation of Glasgow, Glasgow Corporation Transport Motor Buses: An Historical Survey (Glasgow, 1969); B. Longworth, 100 Years of Glasgow Transport (Glasgow, 1994).

41 Corporation of Glasgow, Glasgow Corporation Transport; E. Fitzpayne, A Report on the Future Development of Passenger Traffic in Glasgow (Glasgow, 1948).

42 Glasgow Corporation Transport Committee (hereafter GCTC), Annual Report, 1947; Corporation of Glasgow, Glasgow Corporation Transport; Strathclyde Passenger Transport, Annual Report, 1974.

43 R. Bruce, First Planning Report to the Highways and Planning Committee of the Corporation of the City of Glasgow (Glasgow, 1945); Longworth, 100 Years.

44 GCTC, Annual Report, 1957; Corporation of Glasgow, Glasgow Corporation Transport; Longworth, 100 Years.

45 GCTC, Annual Reports; Longworth, 100 Years; Pacione, Glasgow.

46 Glasgow Herald, 1937-38, 1956-57.

47 GCTC, Annual Reports; Pacione, Glasgow. 
Table 6: Utilization of Corporation public transport in Glasgow, 1899/1900-1969/70

\begin{tabular}{|c|c|c|c|c|c|c|c|c|c|}
\hline $1899 / 1900$ & 90.3 & (127.6) & - & - & - & - & 9.7 & (13.7) & (141.3) \\
\hline $1909 / 10$ & 93.7 & (222.7) & - & - & - & - & 6.3 & $(15.1)$ & (237.8) \\
\hline $1914 / 15$ & 95.8 & (336.3) & - & - & - & - & 4.2 & (14.8) & (351.1) \\
\hline $1919 / 20$ & 97.9 & (509.3) & - & - & - & - & 2.1 & $(11.0)$ & (520.3) \\
\hline $1934 / 35$ & 83.6 & (449.7) & - & - & 13.7 & (73.8) & 2.7 & (14.4) & (537.9) \\
\hline $1940 / 41$ & 78.5 & (478.2) & - & - & 18.7 & (113.5) & 2.8 & $(17.1)$ & (608.8) \\
\hline $1946 / 47$ & 76.6 & (587.3) & - & - & 18.6 & (142.7) & 4.8 & (36.5) & (766.5) \\
\hline $1949 / 50$ & 66.8 & (537.7) & 2.5 & $(20.1)$ & 26.0 & (209.5) & 4.7 & (37.3) & (804.6) \\
\hline $1956 / 57$ & 52.5 & (327.6) & 6.6 & (41.4) & 35.5 & (221.1) & 5.4 & (33.5) & (623.6) \\
\hline
\end{tabular}

* Millions of passenger journeys

** Includes trolley-buses

NB: Data only refer to Glasgow Corporation transport and include journeys for all purposes.

Sources: Glasgow Corporation Tramways Committee, Annual Reports, 1900-28; Glasgow Corporation Transport Committee, Annual Reports, 1929-70; J. Wright and I. Maclean, Circles under the Clyde (Glasgow, 1997), 221. 
1964-65 to 264 1969-70) as commuters and other travellers switched to the private car. ${ }^{48}$

Although carrying a relatively small proportion of travellers, Glasgow commuters in the mid-twentieth century also had the possibility of travelling by rail. A small (six and a half mile) circular underground system was opened in 1896, serving the central area. Originally operated on a cable system by the Glasgow District Subway Company, it was sold to the corporation in 1922 and was electrified in 1935. Never particularly profitable or convenient for most commuters, it had just 50 passenger cars in 1954 and conveyed about 5 per cent of passengers using public transport in the city. ${ }^{49}$ Some Glasgow suburbs were also relatively well served by main line trains from the late nineteenth century and, in the 1940s and 1950s, there were calls to make increasing use of the rail network for commuting journeys. ${ }^{50}$ However, trains only ever served a minority of commuters and the service declined substantially from the 1960s with the closure of a number of lines and suburban stations. ${ }^{51}$ Although, as in Manchester, there had been calls for an integrated public transport system from the 1940s, ${ }^{52}$ little was achieved until the Trans-Clyde Transport System was set up in the late 1970s, based on proposals developed a decade earlier. ${ }^{53}$ However, as elsewhere, by the 1960s Glasgow was experiencing rapid growth in car ownership (from 59 per 1,000 in 1961 to 85 per 1,000 in 1965), ${ }^{54}$ with associated inevitable problems of congestion and urban pollution. Despite some early calls for improved traffic management, ${ }^{55}$ the 1960 s and early 1970s saw extensive road improvement schemes in and around the city. ${ }^{56}$ During the forty years from 1930, commuters in Glasgow repeatedly found their travel options affected by decisions of councillors and others in authority. The Monopoly Act restricted private bus operations, a widely used (though unprofitable) tram system was withdrawn, and most planning decisions increasingly favoured the motor car rather than integrated public transport. The views of Glaswegians on such changes are outlined below.

48 GCTC, Annual Reports.

49 Simpson, 'Urban transport'; Ministry of Transport, Committee of Enquiry; GCTC, Annual Reports.

50 Kellett, The Impact of Railways; Inglis Report, Passenger Transport in Glasgow and District (London, 1951).

51 Pacione, Glasgow.

52 Bruce, First Planning Report; Inglis Report, Passenger Transport.

53 Glasgow Corporation, Greater Glasgow Transportation Study, vols I-V (Glasgow, 1967-75); Greater Glasgow Passenger Transport (hereafter GGPT), Trans-Clyde: Strathclyde Region's Transport System (Glasgow, 1980).

54 R. Hodgson and J. Cullen, 'Recent developments in highway planning in Scotland', Proceedings of the Institute of Civil Engineering, 7106 (1969), 223-45.

55 GGPT, Trans-Clyde.

56 Checkland, The Upas Tree; Gibb, Glasgow; Wannup, 'Glasgow/Clydeside'; Glasgow City Council, Glasgow Fact Sheets; Pacione, Glasgow. 


\section{Attitudes to commuting in Manchester and Glasgow}

Respondents who had lived in Manchester or Glasgow in the 1930s and 1940s almost all viewed the tram system as cheap, reliable and efficient. If they lived in an area served by the tram network, it was almost inevitably seen as the only sensible way to travel to and from work. Quite long tram journeys could be undertaken from many suburbs to the city centre for a few pence and, being on fixed rails, the trams were less affected by thick fogs that restricted the operation of motor buses. The views of respondents support contemporary figures of transport use illustrating the popularity of the tram system in both cities.

Well, there was only one way in those days and that was by tram which was excellent, it were always, there was one along every ten minutes into the city centre. A very good service. (R04, Manchester, male, 1930s)

I mean the trams were very very frequent, all from Altrincham through to Manchester. I mean it was a tremendous tram service. There was one every two to three minutes. (R14, Manchester, male, 1930s)

Well tram cars was the mode, the mode of transport ... That was the normal mode of transport and it was very cheap in those days. The dearest/the longest run I can always remember, was a 25 mile run out to Airdre and it was only two pence ha'penny, and that was the dearest but the fares were very cheap. (R49, Glasgow, male, 1930s)

We used to get a lot of fog in those days and the buses would maybe be off, but the trams used to still run cause they were on rails you see so it was easier for them to you know ... (R21, Glasgow, female, 1940s)

Those commuters who did not use trams in the 1930s and 1940s either travelled on routes not served by the tram network, or chose to walk or cycle, sometimes by preference but often to save money.

The tram wasn't convenient. I could have taken a bus and then a tram ... (R37, Glasgow, female, 1930s)

I could have got on the tram but that would have cost perhaps . . . each way. I preferred to walk (R19, Manchester, female, 1930s)

Oh yes, there was quite a lot of people on the tram cars ... but you didn't take the tram unless you were in a hurry. You walked everywhere. (R51, Glasgow, 1930s)

Not to where I lived no. There were trams on the Eccles New Road and/but not where I lived you know . . . (R20, Manchester, female, 1940s)

Although in Manchester the tram network (and associated tram use) declined slowly, and was progressively replaced by motor buses prior to its demise, in Glasgow, despite some decline in the number of routes, trams continued to carry the majority of commuters until they were 
finally withdrawn. It might thus be expected that Glasgow commuters would have strong feelings about the demise of a form of transport still widely used and generally thought to be cheap and efficient. However, although there had been extensive debate in the contemporary press when the decision to remove trams from Glasgow's streets was taken in $1957,{ }^{57}$ those respondents who recalled the change-over from trams to buses viewed it with equanimity, and seemed to transfer their loyalty from trams to buses without difficulty.

Well there was widespread news that they were, they were stopping the tram, the trams. We were all in advance by it, well advanced warning about buses taking their place ... Well it was, it was well known that they were going to change trams to buses so it was well publicized. (R22, Glasgow, male, 1960s)

The five-year period between the decision to remove trams and their final demise almost certainly allowed travellers to get used to the change. In both cities many respondents were also enthusiastic about the trolley-bus service which partially replaced trams. It was viewed as faster, smoother and quieter than the trams, though only ran for a limited period on restricted routes:

The trams were always a bit rattly, the buses were smelly ... they had trolley buses after the ... trams, and they were much quieter cause they were electric, but had rubber tyres so it was much quieter. (R24, Manchester, male, 1940s)

In both cities the move from trams to bus (and limited trolley-bus) services was essentially a commercial decision taken by the operators (in both cases the corporation). ${ }^{58}$ There is no evidence that large numbers of commuters who used trams disliked them but, equally, most people seemed quite content to switch to buses when forced to do so by a change in service availability. Those people who used buses from the 1930s to the 1960s (both before and after the decline of trams), were almost equally as enthusiastic about them as tram-users were about their chosen mode of transport. In both cities, prior to $c$. 1970, buses were seen as relatively cheap, efficient and convenient. During wartime additional works buses were often provided to get staff to the munitions factories, and these were seen as especially convenient, but by the 1960s some respondents were beginning to be affected by a lack of choice in the public transport available.

Well it was most convenient. Although we had two train stations the bus was nearer me and I just went up the top of the hill, got a bus and right into the Gallowgate in Glasgow. Got off there, walked down three streets, and I was at work. So it was handiness. (R21, Glasgow, female, 1940s)

It was during the war so there was special buses running from various parts of

57 Glasgow Herald, 1957.

58 Manchester Evening News, 1 Jan., 1938; Manchester Daily Dispatch, 12 Jan. 1938; Simon, A Century of City Government; Longworth, 100 Years; Glasgow Herald (various dates). 
Wythenshawe and Northenden and all that to Trafford Park, Manchester you know for the war effort, Metropolitan Vickers, and so at times you could get on those buses if you were lucky enough and early enough. If you didn't get on the bus you had to get on a tram. It was a 37 tram to Brooks Bar, Manchester. Sorry, no not Brooks Bar, Trafford Bar, you could catch a bus that took you into the docks. (R33, Manchester, male, 1940s)

There were so many buses along the main Wilmslow Road, that they came literally every two minutes and never any problem getting into the centre of Manchester. (R62, Manchester, female, 1960s)

By that time my only option really was bus, yes. It was a bit far to go to a train station and certainly by that time all the trams had gone. (Glasgow, male, 1960s)

Those commuters who chose not to use buses had similar reasons to those who disliked trams. In most cases it was a combination of speed, convenience and cost. Some commuters (in both cities) who lived near a train station found this a quicker alternative, and others (especially males) who had to undertake complex cross-city journeys, which entailed changing buses, often chose to cycle instead. The passing of the 1930 Monopoly Act in Glasgow had an especial impact on some commuters in the city. County buses, from outside the city boundary, could not pick up in Glasgow, thus limiting the range of services for some commuters who lived in new estates on the fringes of the city, especially as these estates were rarely served by trams.

No buses were not/there were buses, but when I went in buses came from the county. That's, you know, outside Glasgow, but Glasgow Corporation had a rule that county buses couldn't pick up people inside Glasgow so buses were not ... . not on for the people who lived in, inside the boundary, and we were just inside the boundary ... And even coming out you'd be taken to the bus stop past the boundary to get off because until deregulation some years ago this wasn't allowed. (R22, Glasgow, male, 1930s)

Well, no, I could have gone on the bus or the train. I got the train. I found the bus very tedious, so I preferred to do a brisk walk to Sale station and get a train. I seem to remember it dropping me at Knott Mill station on Deansgate. (R15, Manchester, female, 1940s)

That was when I was in the, what we call the Iron Benders; the men who did the metal work, and that was from Sale to the centre of Manchester again, but there was a train journey then. It was quite easy for the train, and it was faster than the bus. Could have had a bus but the train was quicker. (R04, male, Manchester, 1950s)

There were no buses going that way cause it was across country so . . I I would have had to go into the middle of town and then out again, or changed a couple of times on buses, and I hated buses by then so I got my fresh air on the bike (R24, Manchester, male, 1940s)

From Cheetham to Chadderton. Yes I would. I would cycle there because of, 
because of the reason being that I had to get two or three buses in order to get there because it wasn't on one route you see. (R32, Manchester, male, 1940s)

Well, the bus didn't go that way. I could take one to George Square and walk back down, but the tram car was much more convenient for me. (R23, female, Glasgow, 1950s)

For many of these respondents, changes in urban form during the twentieth century - especially the development of peripheral housing estates - severely restricted individual options for travelling to work.

One theme that comes through very clearly in the responses of commuters who travelled to work in Manchester or Glasgow in the midtwentieth century is the variability of individual experiences. A mode of transport which was convenient and attractive for one person might be quite inappropriate for another because of where they lived and worked, their hours of employment, or simply personal preference. It is thus not possible to make blanket statements about the convenience and use of public transport in either city, and decisions to vary or withdraw particular services affected individuals in very different ways. The varied convenience of a particular transport mode is shown especially clearly in the case of the small Glasgow subway system. Whilst for some it provided a quick and cheap means of transport, for others it was useless because of its limited network.

The subway was so quick and so cheap. You know it was cheaper than the bus / the tram cars at that time. (R52, Glasgow, female, 1930s)

Yes, it was all trams and, well the underground, the subway, that only stopped at Cessnock and that, it didn't go right on. Cessnock and Govan, well it was no use. (R53, Glasgow, female, 1930s)

Exactly the same theme is relevant to the use of private and individual forms of transport. As shown above, the bicycle was an important means of travelling to work for many people (especially men) in the 1930s and 1940s; but the reasons why people chose either to cycle or not to cycle were highly varied. Whilst cycling was seen by many to be cheap, convenient, pleasurable and flexible (especially for those on shift work or travelling cross-city routes), for others it was impracticable, too costly, potentially dangerous and too much effort. It is notable that a number of people who cycled for pleasure did not consider using their bike for commuting, and some people cited problems of storing a cycle securely as a major reason for not using it to travel to work.

Well it [cycling] was really the only way. Cause there was such a tremendous detour using public transport and walking that, well the time factor ... (R14, Manchester, male, 1930s)

Used the cycle. For leisure as well, but it was very handy going into town when the/well money was short for a start ... so going by bike was very much 
cheaper. Save all the bus fares ... Yes, you've got freedom on a bike. You can go when you want and the speed you want. Admitted it was a bit difficult when it was pouring down with rain, but I had a cape and sou'wester. (R24, Manchester, male, 1930s/1940s)

Well I was keen. I had a bicycle at the time you know, so I used the bicycle to get to work. (R46, Glasgow, male, 1940s)

Shift work, yes ... Those times were so that you didn't clash with the manual workers when they were changing shifts. You changed shifts different times to them and of course/and the bike it was so good it gave you that freedom of not having to wait for buses. It would have been easier to use public transport if you had worked normal hours. (R06, Manchester, male, 1950s)

No. You see it's far too busy with the tram cars and we never dreamed of going into the city. The cycle we only used ... to go out to where the Easterhouse scheme was built on you know, but you would go to fields like, the farms. (R23, Glasgow, female, 1930s)

No, I couldn't [cycle], my mother couldn't have afforded one in the first place and I never thought about a bicycle at all . . . no use up here at all because it's so hilly. (R19, Manchester, female, 1930s)

I didn't use a bicycle to go to town. I don't think really there was anywhere to put it you know. (R32, Manchester, male, 1930s)

Oh no, no. I'd never, I'd never have thought about it. Oh no, cycling was a hobby ... it would never have dawned on me to cycle into Glasgow, oh no. (R21, Glasgow, female, 1940s)

No, I didn't. Well I cycled a lot for pleasure but never cycled to work, no . . . I don't know why I didn't. I just never. (R20, Manchester, female, 1940s)

Oh no, I didn't bother because . . . it was the hills. It's quite hilly up here if you know (R49, Glasgow, male, 1960s)

By the 1950s and 1960s an increasing number of men were travelling to work by car, and the reasons given for either using or not using cars were very similar to those stated for using other forms of transport. Cars were quick, convenient and comfortable, especially for cross-town journeys (increasingly common with the decentralization of homes and workplaces), and for trips that combined a number of functions. In the 1960s, as public transport was beginning to be less frequent and attractive, it was also still relatively easy to drive into the city centres and find a parking space. Indeed, one respondent suggested that parking a car was rather easier than finding a secure place to leave a cycle, though concern about the security of parked cars was expressed by another respondent, and one man found parking in Manchester a problem in the 1940s. There is also evidence of a change in attitudes from the 1930s to the 1960s. The small number of respondents who owned cars in the 1940s and 1950s often used them mainly for pleasure and were quite 
likely to use public transport to commute to work; but by the 1960s most people who owned a car would use it in preference to other forms of transport.

There is a bus service, but the train's much better really. I'd have motored in but then there was parking. It was as difficult as it is now. (R07, Manchester, male, 1940s)

If you had access to a car at that stage, ... you would have used that for leisure only. It would not have occurred to you to use it for work. (R04, Manchester, male, 1950s)

Yes I got a car at that point because to travel to $x$ was quite awkward. To do it by public transport would mean ... a bus journey, an underground journey, and another bus journey . . . so it really wasn't terribly convenient, so I'd managed to accrue a little capital and I bought a car. (R39, Glasgow, male, 1950s)

It was easy to park the car and it was safe cause you can lock it, but with a bike you can lock it and still get/still lose it ... you could pick up the whole thing and take it away. (R24, Manchester, male, 1960s)

Yes you could, you could park on the streets. If you, if you didn't you could, you could go on to the car park ... but you wanted to be as close as you could ... The nearer work you could get the safer your car was. (R60, Manchester, 1960s)

I did, did get a car while I was working there eventually. I mean I, I don't remember that being the deciding factor. I thought it was more convenient to have a car. You know more comfortable than riding around on a motor bike in the wind and the snow in the winter. (R64, Manchester, male, 1960s)

As shown by the aggregate statistics (above) relatively few women travelled to work by car in the 1950s and 1960s, and even fewer drove themselves. Female interview respondents were much more likely to be given a lift by their husband or a male work colleague, and even if they learned to drive they rarely owned or had regular access to a car in the 1960s. In both Manchester and Glasgow female workers remained heavily dependent on public transport in the 1960s, and were thus particularly affected by the inconvenience of some bus and train services.

I must have passed my test soon after I started working there because I know that I did take my father's car once or twice if I had, you know, a lot of things to carry. (R75, Glasgow, female, 1960s)

I used to get the bus and then one of the teachers lived in the next road to me and drove, and said how I was getting into school very early because of the timing of the bus ... and he said well look you know come with me, so that made it easier, and then in the meantime I started to learn to drive and never liked it. (R25, Manchester, female, 1960s)

My dad occasionally gave me a lift into the centre of Manchester, but he tended to start work that bit earlier. . . So, yes, occasionally my dad would give me a lift in if, if he was going in a bit later. (R62, Manchester, female, 1960s). 


\section{Conclusion: the links between commuting, transport and urban form}

This paper has examined changes in the provision of public transport and in patterns of commuting in Glasgow and Manchester, focusing especially on the attitudes of travellers to different forms of transport, and the links between commuter preferences, transport provision and urban form. It has not been possible to provide a complete history of transport and commuting in the two cities in a single paper, and much remains to be said about both Glasgow and Manchester. However, a number of key themes have emerged which shed light on processes of change in urban travel behaviour from the 1930s to the 1960s. These themes are likely to be generalizable to many other urban areas in Britain, though it is well known that commuting patterns and transport provision in London were and remain distinctive. ${ }^{59}$

Investigation of the pattern and process of commuting at the local level also exemplifies many themes of much broader significance. As shown in Figure 1, decisions about the journey to work are closely related to a wide range of economic, social, cultural and technological factors that have influenced changing urban form and society. Case studies of Manchester and Glasgow have illustrated some of these relationships. However, the paper has placed especial emphasis on the attitudes and decisions of individual commuters in the two cities. It is clear that personal decisions to use particular transport modes to travel to work, and individual reactions to issues such as traffic congestion, problems with parking or security, changes to public transport provision, and the decentralization of homes and workplaces were highly varied. A transport system that was convenient for one commuter could be quite unsuitable for someone else, depending on such factors as the location of home and employment, hours of work, income, family responsibilities and personal preferences. One system of public transport is thus unlikely to have ever met the requirements of all commuters, or to have received universal acclaim; though the extensive tram network which operated in Glasgow from the 1930s to the 1960s probably came nearest to this position. However, it can be suggested that if urban transport in any city is to meet the varied demands of commuters, it should offer a degree of choice and flexibility that is unlikely to be available within a single mode. Thus commuters were best served when there was a choice of transport within the two towns, as was the case for much of the period 1930 to 1960. But the gradual reduction in public transport provision and the increased reliance on the motor car has progressively restricted the options of commuters.

59 Barker and Robbins, A History of London Transport. 
The links between changes in urban form, transport provision and commuting patterns are complex. In both Glasgow and Manchester it can be suggested that urban growth, and associated major changes in urban form, were largely independent of transport provision. Thus suburban industrial and housing estates were mostly planned and developed ahead of the provision of public transport to these locations. Much the same conclusions have been drawn about the impact of railways on urban growth in the nineteenth century. ${ }^{60}$ However, suburban development in Glasgow and Manchester did lead to the wider introduction of new forms of public transport in both cities. It was not considered profitable to lay tram lines to most new suburban estates, and it was on these routes that motor buses were first introduced. This gave momentum to campaigns in both cities for the substitution of trams by motor buses, despite the fact that many commuters continued to find trams both convenient and reliable. Decisions taken by planners and councillors to change the nature of public transport provision were thus taken primarily on commercial grounds, and reflected a perceived superiority of new technology over old. They rarely reflected the views of commuters, but in both Manchester and Glasgow those who travelled to work daily in the city quickly adjusted to such changes. Whatever the system provided it was liked and seen to be convenient by some, but criticized by others.

The issues that preoccupied most people were concerned mainly with the convenience, flexibility, cost, speed and comfort of urban commuter transport. Such issues were important (in different combinations) for most travellers, but they were interpreted in a variety of ways. Whereas for some (especially men) cycling met requirements of speed, flexibility and cost, for others the bus or tram was more appropriate. It can be suggested that the factors that have governed commuters' choices of transport modes have remained quite stable from the 1930s to the 1960s. However, the gradual reduction in the range of public transport options available, and changes in urban form that have necessitated increasingly complex cross-city movements for many, have made it more difficult to meet such demands. By the 1960s many men found that their commuting preferences could only be met through the use of private cars, with inevitable consequences for urban traffic congestion and pollution in the second half of the twentieth century. The complexity of factors involved, and the individuality of commuters' responses to different transport systems, suggest that urban transport systems need to provide choice for the traveller, and to be sensitive to local urban structures. 